pp. $15-28$

\author{
Agnieszka KOSEK \\ ORCID: 0000-0001-5900-1794 \\ Uniwersytet Pedagogiczny im. KEN \\ w Krakowie
}

\author{
Agata WOLSKA \\ ORCID: 0000-0003-4673-0909 \\ Uniwersytet Pedagogiczny im. KEN \\ w Krakowie
}

\title{
Budowanie relacji interpersonalnych w klasach I-III w warunkach nauczania zdalnego
}

\begin{abstract}
Building Interpersonal Relationships in Grades 1-3 in Distance Learning Conditions

Interpersonal relations are an integral part of living in society. Interpersonal competences combine activities related to communication, making new friends, solving problems or cooperating with others. Therefore, they are extremely important at every educational stage. However, building proper relations among education participants becomes more difficult when schools around the world switch to distance learning due to the COVID-19 virus pandemic. Relations between teachers and students, as well as among classmates, often undergoes various modifications, frequently deteriorating the quality of mutual contact. Distance education has also changed the role of pupils' parents. The new situation often required from them to adapt to their child's schedule in order to support them and help them in learning. This particularly applies to the families with younger children. In order to explain these issues, this article will present the results of research conducted among teachers and parents of pupils from grades 1-3 on the relationship at a pupil-pupil and a student-teacher level. The didactic and educational activities of teachers that are undertaken by them in order to improve contact on both these levels in the face of the new reality will also be discussed. The article will also address the topic of transformations of the abovementioned relations, which took place during and after the transition to compulsory distance learning.
\end{abstract}

Keywords: pandemic, remote learning, interpersonal relations, peer relations, pupil-teacher relations, teacher-parent relations

Słowa kluczowe: pandemia, edukacja zdalna, relacje interpersonalne, relacje rówieśnicze, relacje uczeń-nauczyciel, relacje nauczyciel-rodzic 


\section{Wprowadzenie}

Środowisko edukacyjne i wychowawcze stanowi jedną z najważniejszych przestrzeni życiowych młodego człowieka. W procesie wieloletniego kształcenia i wychowania objęte nim osoby rozwijają różne kompetencje przydatne w dorosłym, samodzielnym życiu. Szkoła wyposaża uczniów nie tylko w wiedzę i umiejętności, ale też pomaga rozwinąć jednostce osobowość i pielęgnować przyjęty system wartości. Osiągnięcie tego wszystkiego nie byłoby możliwe, gdyby nie tworzące się pomiędzy uczestnikami edukacji relacje interpersonalne.

To właśnie jakość wzajemnych interakcji decyduje w dużym stopniu o charakterze środowiska, w którym młody człowiek ma się rozwijać. Beata Jakimiuk zauważa, iż „szkoła to nie tylko instytucja - przede wszystkim tworzą ją ludzie, którzy wnoszą do niej swoje potrzeby i swój sposób widzenia świata. Społeczność szkolna to grupa ludzi, którzy wzajemnie się ubogacają, oddziałując na siebie swoją osobowością, postawą i wyznawanymi wartościami” (2016, s. 121). Dlatego też jednym $\mathrm{z}$ najważniejszych zadań, które stawiane są przed nauczycielem, jest budowanie i utrzymywanie dobrych relacji z innymi członkami szkolnej społeczności, w tym z uczniami i ich rodzicami.

Czynniki, które sprzyjają tworzeniu pozytywnych relacji interpersonalnych to m.in: skuteczna komunikacja (oparta na kontakcie bezpośrednim), okazywanie drugiej osobie szacunku, serdeczności i uznania, rozumienie emocji i sytuacji innych oraz wzajemne zaufanie (Jakimiuk, 2016; Musiał, 2016). Zbudowanie relacji nauczyciela $z$ uczniem na wymienionych zasadach stwarza temu drugiemu różnorodne perspektywy rozwojowe, począwszy od zdobywania wiedzy i umiejętności, przez właściwe rozumienie uczenia się, aż wreszcie dostrzeżenie, że w tym procesie odgrywa niezwykle ważną rolę, stając się podmiotem nauczania (Brophy, 1998; za: Dubis, 2017).

Równie ważne są relacje tworzące się pomiędzy rówieśnikami w zespole klasowym. Dzięki nim każdy uczeń ma możliwość rozwijania kompetencji interpersonalnych, takich jak: nawiązywanie nowych znajomości, komunikowanie się, rozwiązywanie problemów i sytuacji konfliktowych oraz współpraca $z$ innymi ludźmi (Wolska, 2021).

Do niedawna proces ten nie podlegał większym zewnętrznym zakłóceniom. Uczniowie i nauczyciele mogli w sprzyjających warunkach odkrywać swoje osobowości i uczyć się wzajemnego szacunku i współpracy. Wszystko jednak zmieniło się, gdy na początku 2020 r. świat stanął przed globalnym zagrożeniem pandemią wirusa COVID-19. 


\section{Relacje interpersonalne w klasie w czasie pandemii COVID-19 - przegląd badań}

Po roku trwania pandemii COVID-19 dostrzegamy coraz więcej negatywnych skutków izolacji społecznej. Szczególnie dotyczy to dzieci, które zostały odizolowane od swoich rówieśników i wychowawców w szkole. W trakcie realizowania edukacji zdalnej modyfikacjom uległy dwa najważniejsze obszary relacji panujących wewnątrz zespołu klasowego: relacje rówieśnicze oraz relacje uczeńnauczyciel. Oba rodzaje relacji bezpośrednio wiążą się z jakością edukacji, stając się w ten sposób jej kluczowym elementem (Pyżalski, Stunża, 2020).

Naukowcy z Chicago specjalizujący się $\mathrm{w}$ badaniach edukacyjnych już na początku pandemii wyrażali obawy związane z psychicznymi skutkami utraty przez dzieci i młodzież bezpośredniego kontaktu z przyjaciółmi i nauczycielami. Środowisko szkolne ma kluczowe znaczenie dla wspierania motywacji do uczenia się i rozwoju społecznego, wielu uczniom daje poczucie bezpieczeństwa i emocjonalne wsparcie. Zmiana znanej uczniom rzeczywistości na edukację zdalną u części z nich prowadzi do utraty pewności siebie. Dodatkowo w kontaktach on-line dzieci i młodzież zostają pozbawieni możliwości rozwijania podstawowych umiejętności społecznych, takich jak rozumienie sytuacji i uczuć drugiej osoby czy dostosowywania reakcji do określonych sytuacji. Psycholog Beth Doll zauważa, że większość uczniów nie jest przygotowana do nauki w izolacji (za: Stringer, 2020). Pozbawieni motywacji w postaci bezpośrednich relacji $\mathrm{z}$ innymi uczestnikami edukacji często bagatelizują nauczanie zdalne i w trakcie jego trwania skupiają uwagę na innych aktywnościach, np. na grach on-line (Buchner, Wierzbicka, 2020).

Wybuch pandemii sprawił, że nauczyciele $z$ dnia na dzień stanęli przed nowymi wyzwaniami. Zdaniem Jacka Pyżalskiego (2020]) najważniejszym z nich okazało się "zachowanie, podtrzymanie i ulepszanie relacji międzyludzkich, które manifestują się na płaszczyźnie edukacyjnej” (s. 25). Do jej najważniejszych wymiarów autor zalicza: relacje uczeń-nauczyciel, relacje rówieśnicze oraz relacje nauczyciel-rodzina ucznia. Jego zdaniem stanowią one podstawe w piramidzie priorytetów (ryc. 1), które uwidaczniają się w trakcie nauczania w warunkach zdalnych.

W nowej sytuacji, w jakiej znaleźli się uczestnicy edukacji, kluczowym sojusznikiem mógł okazać się rodzic dziecka. Jego rola w trakcie edukacji zdalnej uległa zmianie - stała się ważniejsza i zyskała na znaczeniu. Zaangażowanie ze strony rodziców było $\mathrm{i}$ jest istotne przede wszystkim w przypadku klas I-III, w których bez ich pomocy edukacja w warunkach zdalnych byłaby niemożliwa (Buchner, Wierzbicka, 2020).

Tuż po rozpoczęciu nauki zdalnej w polskich szkołach wielu naukowców podjęło obszerne badania na temat nowej sytuacji edukacyjnej i społecznej 


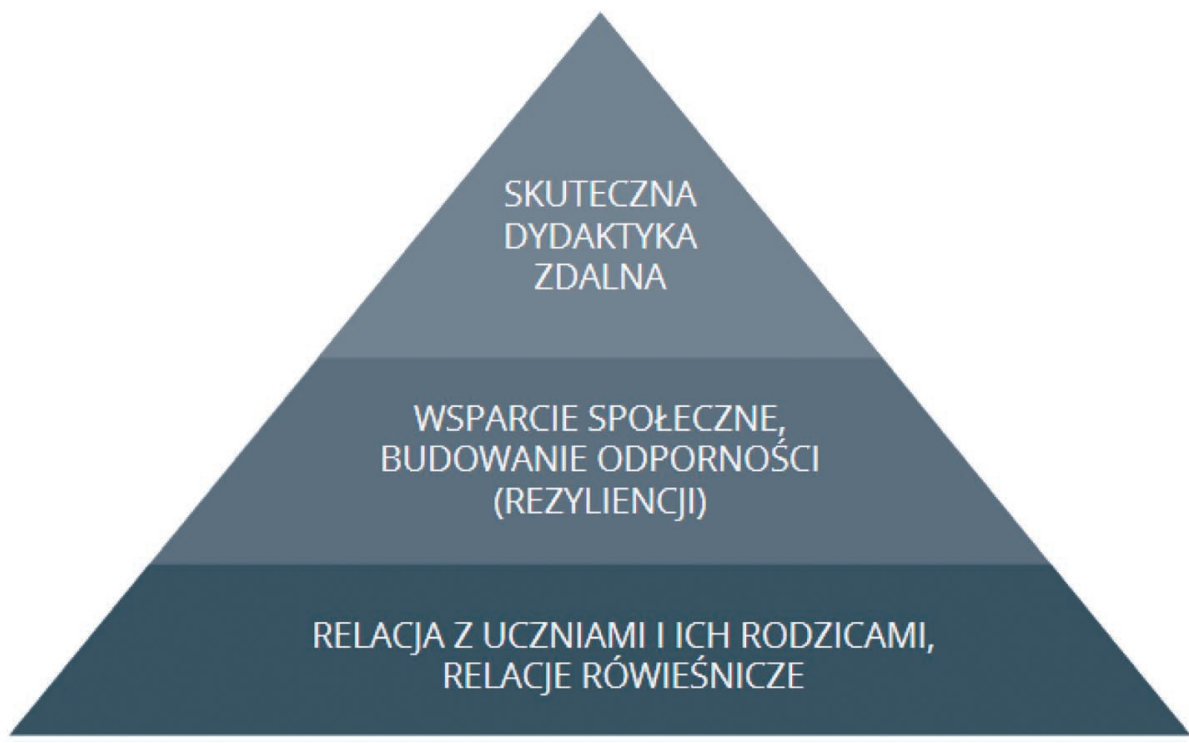

Ryc. 1. Priorytety edukacji zdalnej w warunkach izolacji spowodowanej pandemią. Źródło: Pyżalski, 2020, s. 26.

uczniów na różnych poziomach kształcenia. Najczęściej jednak badania te koncentrowały się na uczniach starszych klas szkoły podstawowej i szkoły średniej.

Badania przeprowadzone przez Annę Buchner i Marię Wierzbicką (2020) potwierdziły, że izolacja społeczna w czasie lockdownu stała się zbyt dużym obciążeniem psychicznym dla większości uczennic i uczniów. $\mathrm{Z}$ relacji biorących udział w badaniu nauczycieli wynika, że decydującym czynnikiem złego samopoczucia dzieci był brak kontaktu z rówieśnikami. Ograniczenia te stały się szczególnie uciążliwe dla dzieci młodszych. Większość z nich nie potrafiła jeszcze $\mathrm{w}$ tym czasie biegle czytać i pisać, co utrudniało komunikowanie się za pomocą portali społecznościowych. Dodatkowym czynnikiem ograniczającym możliwości porozumiewania się wśród młodszych dzieci był często brak własnego sprzętu z zainstalowanymi komunikatorami społecznymi. Nauczyciele zgodnie przyznają, że w ich pracy decydujące znaczenie ma relacja, jaką tworzą ze swoimi podopiecznymi. Zbudowanie relacji opartej na wzajemnym zaufaniu wymaga jednak czasu. Dlatego też w wyjątkowo trudnej sytuacji znaleźli się uczniowie i nauczyciele klas pierwszych, którzy pracowali ze sobą od niedawna.

Na obciążenia psychiczne, z jakimi zmagają się dzieci i młodzież w czasie pandemii COVID-19, zwrócono również uwagę w raporcie Thinking about $\mathrm{Pe}$ dagogy in an Unfolding Pandemic, przygotowanym na zlecenie globalnej federa- 
cji związków zawodowych nauczycieli (Education International) i organizacji UNESCO (United Nations Educational, Scientific and Cultural Organization). Jako szczególnie obciążające emocjonalnie czynniki w czasie trwania izolacji społecznej wymieniono:

— strach przed utratą bliskiej osoby (szczególnie nasila się u dzieci osób pracujących w służbie zdrowia);

- utratę stałej, przewidywalnej struktury edukacji;

- zaburzenie naturalnego procesu żałoby w przypadku śmierci bliskiej osoby (brak możliwości pożegnania się z umierającym członkiem rodziny, częściowa lub całkowita rezygnacja $z$ tradycyjnych obrzędów religijnych);

- ograniczenie kontaktu $\mathrm{z}$ rodziną, znajomymi i kolegami z klasy - czynnik ten okazał się szczególnie dotkliwy dla uczniów młodszych klas szkoły podstawowej (Doucet, Netolicky, Timmers, Tuscano, 2020).

Relacje interpersonalne w czasie pandemii COVID-19 wśród uczniów szkoły podstawowej stały się tematem badań ankietowych Anny Bieganowskiej-Skórki oraz Doroty Pankowskiej (2020). Grupę badawczą (360 osób) stanowili jednak uczniowie dwóch najstarszych klas szkoły podstawowej. Opracowane wyniki wskazują, że $68,4 \%$ respondentów odczuwa brak kontaktów z rówieśnikami. Co więcej, blisko $60 \%$ uważa, że izolacja prowadzi do nasilenia się konfliktów i aktów przemocy. Aż jedna czwarta ankietowanych stała się ofiarami hejtu. Na szczęście większość uczniów (70\%) otrzymuje odpowiednie wsparcie ze strony wychowawcy klasy, psychologa i pedagoga szkolnego. Uczniowie klas VII i VIII dostrzegają też znaczenie współpracy nauczycieli i rodziców w podtrzymywaniu prawidłowych relacji w klasie.

W projekcie badawczym „Zdalne nauczanie a adaptacja do warunków społecznych w czasie epidemii koronawirusa" kwestionariusz ankiety zaadresowano do trzech grup: uczniów klas VI-VIII (grupa I - 1284 osoby), ich rodziców (grupa II - 979 osób) oraz wszystkich nauczycieli przedmiotowych, prowadzących zajęcia w klasach VI-VIII (grupa III - 671 osób). W uzyskanych danych należy m.in. zwrócić uwagę na to, iż połowa biorących udział w badaniu uczniów przyznała, że ich relacje rówieśnicze przed pandemią były dużo lub trochę lepsze. Liczną grupę (40\%) stanowili też uczniowie, którzy nie zauważyli zmian pod tym względem. Prawie 5\% młodych ludzi biorących udział w badaniu stwierdziło natomiast, że przed pandemią ich relacje z kolegami z klasy były gorsze. W przypadku relacji nauczyciel-uczeń zmiany odczuło tylko $27 \%$ uczniów. Zdecydowana większość uważała, że uległy one pogorszeniu, a tylko niewielka grupa (4\%) dostrzegała poprawę w relacji z nauczycielami.

W opinii respondentów z I i II grupy ważną rolę w czasie pandemii pełniły relacje w rodzinach. Choć większość rodziców, jak i ich dzieci nie dostrzega znaczących zmian $\mathrm{w}$ relacjach mędzy domownikami, to podobny odsetek 
uczniów zauważa ich pogorszenie i polepszenie (odpowiednio około 13\% i 12\%). Zmianą zauważaną przez respondentów jest czasu spędzany wspólnie z rodziną. $30 \%$ uczniów i $29 \%$ rodziców twierdzi, że w trakcie pandemii spędza się go wspólnie znacznie więcej. Jest też jednak grupa (12\% dzieci i 11\% opiekunów), która dostrzega, że wspólne spędzanie czasu uległo skróceniu (Ptaszek i in., 2020).

Jak już wspominano, rodzina ucznia, który kształci się zdalnie, odgrywa niezwykle ważną rolę. Pielęgnując relacje międzyludzkie w gronie domowników i zapewniając dziecku wsparcie emocjonalne, pomaga mu w adaptacji do nowych warunków. Dlatego obecność najbliższych (w szczególności rodziców/ opiekunów) w czasie trwania edukacji na odległość jest dla dziecka tak bardzo ważnym czynnikiem. Znaczenia nabierać będzie $\mathrm{w}$ tym przypadku również relacja nauczyciel-rodzice ucznia. Ich współpraca może przynieść wiele korzyści. Niestety, wyniki badań zaprezentowane w raporcie Edukacja zdalna w czasie pandemii wskazuja, że pandemiczna sytuacja miała raczej negatywny wpływ na relacje łączące nauczycieli z rodzicami uczniów. Zdaniem respondentów u podłoża problemów tkwią różnorodne, często wzajemnie sprzeczne oczekiwania rodziców. Część z nich uważa, że w czasie edukacji zdalnej są nadmiernie obciążeni. Wyrażają swoje rozczarowanie i opór wobec angażowania ich w ten proces (Buchner, Majchrzak, Wierzbicka, 2020).

\section{Badania własne}

Nauka w systemie zdalnym wymogła na szkolnej społeczności wiele zmian. W niezwykle kłopotliwej sytuacji znaleźli się nauczyciele i uczniowie edukacji wczesnoszkolnej, a także towarzyszący swoim dzieciom rodzice. Analiza dostępnej literatury przedmiotu nie dostarcza jednak pełnych informacji na ten temat, postanowiono więc podjąć stosowne badania.

Ich celem było zbadanie sposobów budowania i podtrzymywania relacji interpersonalnych w klasie podczas pandemii. Główny problem badawczy został ujęty w pytaniu: W jaki sposób budowane są relacje interpersonalne w klasach I-III w warunkach nauczania zdalnego? Problem główny konkretyzują problemy szczegółowe, sformułowane następująco:

- Czy i w jaki sposób zmieniły się relacje interpersonalne uczniów klas I-III w warunkach nauczania zdalnego?

- Czy i w jaki sposób zmieniły się relacje interpersonalne pomiędzy uczniami i nauczycielem w warunkach nauczania zdalnego?

- Jakie sposoby budowania i podtrzymywania relacji interpersonalnych wśród uczniów oraz pomiędzy nauczycielem i jego wychowankami są stosowane przez nauczycieli klas I-III w czasie spotkań on-line? 
- Jaką rolę $\mathrm{w}$ podtrzymywaniu relacji interpersonalnych $\mathrm{w}$ klasie $\mathrm{w}$ warunkach zdalnego nauczania odgrywają rodzice uczniów?

W badaniach zastosowano strategię ilościową, a wykorzystana metoda to sondaż diagnostyczny. Techniką użytą $\mathrm{w}$ badaniach była ankieta, narzędziem badawczym zaś - dwa kwestionariusze ankiety (jeden, skierowany do nauczycieli klas I-III, oraz drugi, skierowany do rodziców uczniów edukacji wczesnoszkolnej). Pytania zawarte w kwestionariuszach miały charakter zamknięty, półotwarty oraz otwarty.

Pierwszą grupę badawczą tworzyło 35 nauczycielek klas I-III w różnym wie$\mathrm{ku}$ oraz z różnym stażem pracy. Drugą grupę badawczą stanowiło 37 rodziców dzieci uczęszczających do klas początkowych. Respondenci pochodzili z różnych województw, a największą grupę stanowili mieszkańcy województwa małopolskiego. Wśród badanych znalazło się rodzice 17 dziewczynek oraz 20 chłopców, z czego 11 dzieci uczęszczało do klasy pierwszej, po 13 zaś do klasy drugiej i trzeciej. Badania zostały przeprowadzone w lutym 2021 r., a respondenci $z$ obu grup udzielali odpowiedzi anonimowo, wypełniając internetowy formularz.

Uzyskane wyniki badań dotyczyły dwóch kwestii: dydaktyczno-wychowawczych działań nauczycieli oraz wsparcia ze strony rodziców uczniów klas I-III $\mathrm{w}$ budowaniu i podtrzymywaniu relacji interpersonalnych w klasie.

\section{Relacje interpersonalne w klasie w warunkach nauczania zdalnego}

Z przeprowadzonych badań wynika, iż nauczyciele i rodzice odmiennie postrzegają relacje interpersonalne uczniów klas I-III w warunkach nauczania zdalnego. Według większości nauczycieli (26 osób - 74\%) relacje dzieci uległy zmianie.

Inaczej jest w przypadku rodziców. Prawie połowa (18 osób - 49\%) nie dostrzega żadnych zmian, a 11 osób (30\%) nie ma na ten temat zdania. Zmiany wśród dzieci dostrzega tylko 8 rodziców (21\%).

Biorąc pod uwagę kontakty uczniów klas I-III z rówieśnikami poza lekcjami on-line, należy odnieść się do dwóch ważnych czynników: częstotliwości oraz sposobu kontaktowania się. Na podstawie wypowiedzi biorących udział $\mathrm{w}$ badaniu rodziców uczniów edukacji wczesnoszkolnej ustalono, że nieznaczna część uczniów nie kontaktowała się z rówieśnikami w ogóle, a w niewielkiej grupie kontakt ten wystepował sporadycznie. Częstsze kontakty występowały u ponad jednej trzeciej uczniów, którzy porozumiewali się ze sobą nawet kilka razy w tygodniu, około jedna czwarta dzieci robiła to codziennie, a niewielki odsetek kilka razy dziennie. Szczegółowe wyniki zostały przedstawione na wykresie (ryc. 2). 


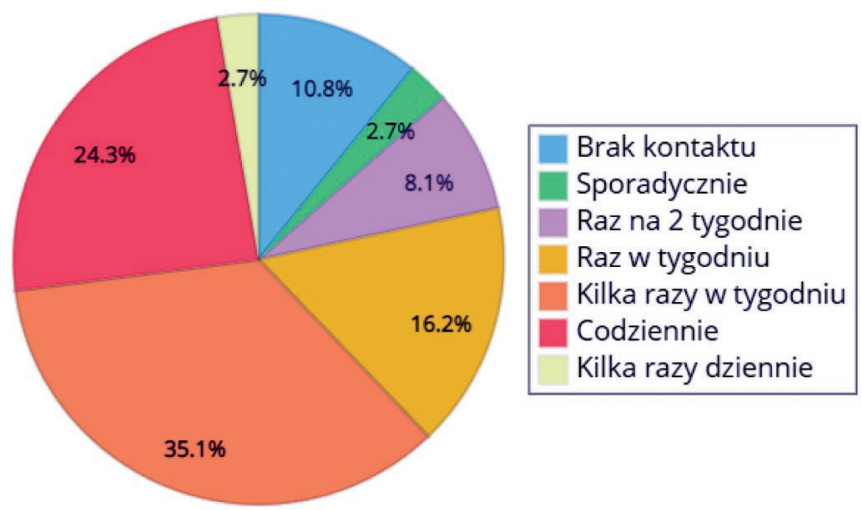

Ryc. 2. Częstotliwość kontaktów rówieśniczych u uczniów klas I-III w okresie pandemii. Opracowanie własne

Jeśli chodzi o sposób kontaktowania się, najczęściej preferowaną formą były wideorozmowy, następnie portale społecznościowe, rozmowy telefoniczne, inne sposoby komunikacji (spotkania w domach, zabawy na świeżym powietrzu) oraz najrzadziej wybierane - esemesy.

W przypadku relacji na poziomie nauczyciel-uczeń ponad połowa nauczycieli (22 osoby - 63\%) stwierdziła, że relacja ta się nie zmieniła. Pozostała część respondentów (37\%) uważała, że relacja ta uległa zmianie, co objawia się głównie zwiększeniem dystansu wobec wychowawcy klasy. Zwrócili oni także uwagę, że dzieci rzadziej rozmawiają o swoich problemach i trudnościach oraz odczuwają zmęczenie, spowodowane dużą ilością czasu spędzonego przed komputerem:

Zwiększyt się dystans, dzieci nie maja tyle odwagi, by porozmawiać o swoich trudnościach (nauczyciel klasy I).

Dystans, zmęczenie ciagta praca przy komputerze powodujące zniechęcenie do przedmiotu i nauczyciela (nauczyciel klasy III).

Niektórzy nauczyciele dostrzegli także pozytywne zmiany, np. większą niż wcześniej otwartość dzieci:

Uczniowie zadaja więcej pytań do zajęć, sq bardziej otwarci niż na żywo, komunikuja się też między soba, jak maja problem (nauczyciel klasy I). 


\section{Sposoby budowania i podtrzymywania relacji interpersonalnych w klasie stosowane przez nauczycieli edukacji wczesnoszkolnej w czasie spotkań on-line}

Nauczyciele podczas kształcenia na odległość stosowali rozmaite sposoby budowania i podtrzymywania relacji na różnych jej poziomach. Najczęstszym działaniem wskazanym przez zdecydowaną większość nauczycieli (91\%) było wspominanie pozytywnych doświadczeń i osiągnięć uczniów w celu potrzymania relacji rówieśniczych. Pozostałe odpowiedzi respondentów zostały zaprezentowane w tabeli 1.

Tabela 1. Sposoby budowania i podtrzymywania relacji interpersonalnych przez nauczycieli edukacji wczesnoszkolnej na poziomie uczeń-uczeń)

\begin{tabular}{|l|c|}
\hline \multicolumn{1}{|c|}{ Uczeń-uczeń } & Liczba odpowiedzi \\
\hline Wspominanie pozytywnych doświadczeń i osiągnięć uczniów & 32 \\
\hline $\begin{array}{l}\text { Stosowanie netykiety (wzajemny szacunek, uważne słuchanie innych, } \\
\text { nieprzerywanie, gdy ktoś mówi) }\end{array}$ & 24 \\
\hline $\begin{array}{l}\text { Nawiązywanie do wspólnych przeżyć sprzed pandemii } \\
\text { (np. wycieczki klasowe, urodziny, uroczystości szkolne) }\end{array}$ & 21 \\
\hline Świętowanie on-line urodzin uczniów lub innych istotnych wydarzeń & 16 \\
\hline Zapraszanie gości na zajęcia on-line & 10 \\
\hline Inne & 4 \\
\hline
\end{tabular}

Opracowanie własne.

Aby podtrzymać relację z uczniami, nauczyciele interesowali się ich nastrojem i doświadczeniami, a także wprowadzali na zajęcia humor. Takie sposoby stosowało odpowiednio $86 \%$ i $83 \%$ nauczycieli. Szczegółowe informacje na temat sposobów budowania i podtrzymywania relacji interpersonalnych przez nauczycieli edukacji wczesnoszkolnej na poziomie uczeń-nauczyciel prezentuje tabela 2.

Badani nauczyciele są świadomi, że dla podtrzymywania pozytywnych relacji w klasie znaczenie mogą też mieć różnorodne metody czy formy pracy. Wyniki badań wskazują, że ponad połowa nauczycieli uważa, iż podtrzymywaniu relacji służy metoda projektowa. Podobnie sądzą o edukacji rówieśniczej, której pozytywne znaczenie przypisuje zdecydowana większość nauczycieli. Stosunkowo często nauczyciele pracowali metodą projektową oraz stosowali pracę indywidualną uczniów, zawsze była to jednak praca $\mathrm{z}$ całą klasą.

Do prowadzenia zajęć oraz do kontaktowania się z uczniami nauczyciele edukacji wczesnoszkolnej potrzebowali różnych narzędzi multimedialnych. Zdecydowana większość respondentów zadeklarowała, iż używa platform komunikacyjnych. Gry i zabawy edukacyjne są wykorzystywane przez około trzy 
Tabela 2. Sposoby budowania i podtrzymywania relacji interpersonalnych przez nauczycieli edukacji wczesnoszkolnej na poziomie uczeń-nauczyciel

\begin{tabular}{|l|c|}
\hline Uczeń-nauczyciel & Liczba odpowiedzi \\
\hline Zainteresowanie nastrojem i doświadczeniami uczniów & 30 \\
\hline Wprowadzenie na zajęciach humoru & 29 \\
\hline $\begin{array}{l}\text { Zachęcanie uczniów do dzielenia się aktualnymi przeżyciami w ciągu dnia } \\
\text { (opowiadanie o różnych wydarzeniach, pokazywanie zdjęć) }\end{array}$ & 27 \\
\hline Dzielenie się z uczniami radami/pomysłami, co robić, by lepiej się czuć & 25 \\
\hline $\begin{array}{l}\text { Pokazywanie uczniom fragmentów swojej codzienności (filmiki ze } \\
\text { zwierzętami, zdjęcia podczas domowych czynności) }\end{array}$ & 13 \\
\hline Inne & 2 \\
\hline
\end{tabular}

Opracowanie własne.

czwarte nauczycieli, ponad połowa przyznaje, że korzysta z programów i aplikacji wspomagających proces uczenia. Pozostałe narzędzia multimedialne nie są powszechnie stosowane w pracy zdalnej. Należą do nich portale społecznościowe, z których korzysta mniej niż połowa wychowawców klas początkowych, programy dotyczące twórczości artystycznej, np. programów graficznych używa około dwóch piątych badanych, oraz platformy e-learningowe typu Moodle, których wykorzystywanie deklaruje blisko jedna trzecia respondentów. To pokazuje, które narzędzia multimedialne zdaniem nauczycieli są skutecznym pośrednikiem w pracy z małymi dziećmi.

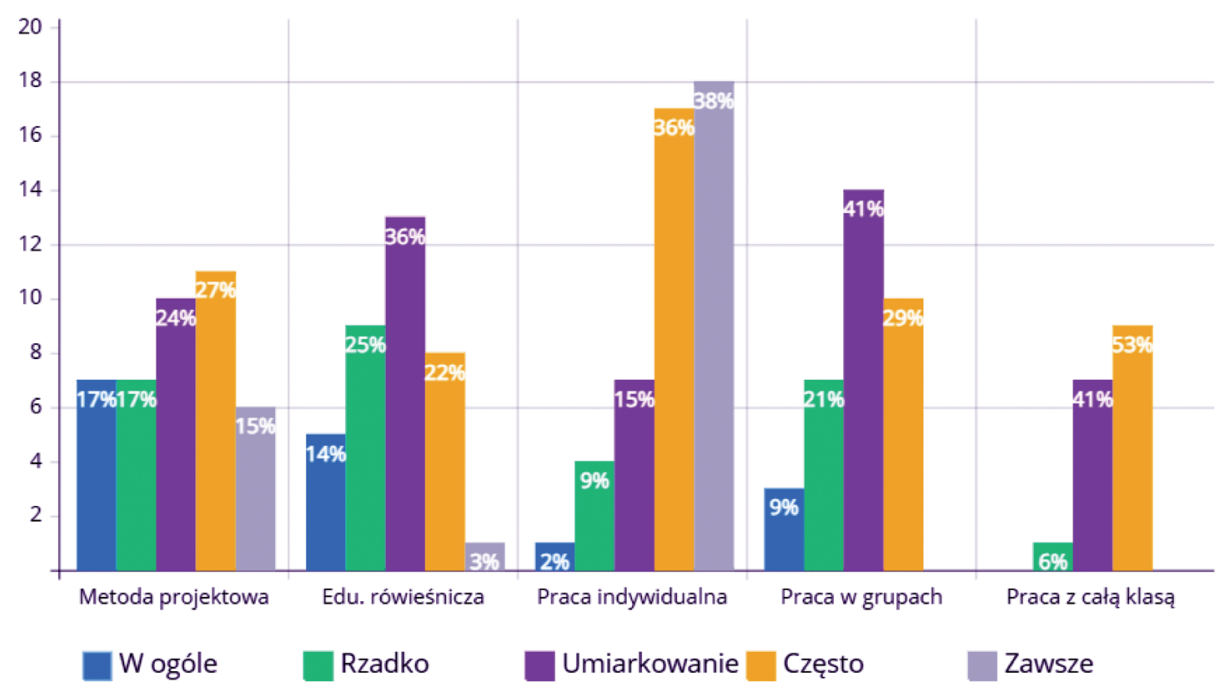

Ryc. 3. Metody i formy pracy wykorzystywane przez nauczycieli podczas nauczania zdalnego. Opracowanie własne 


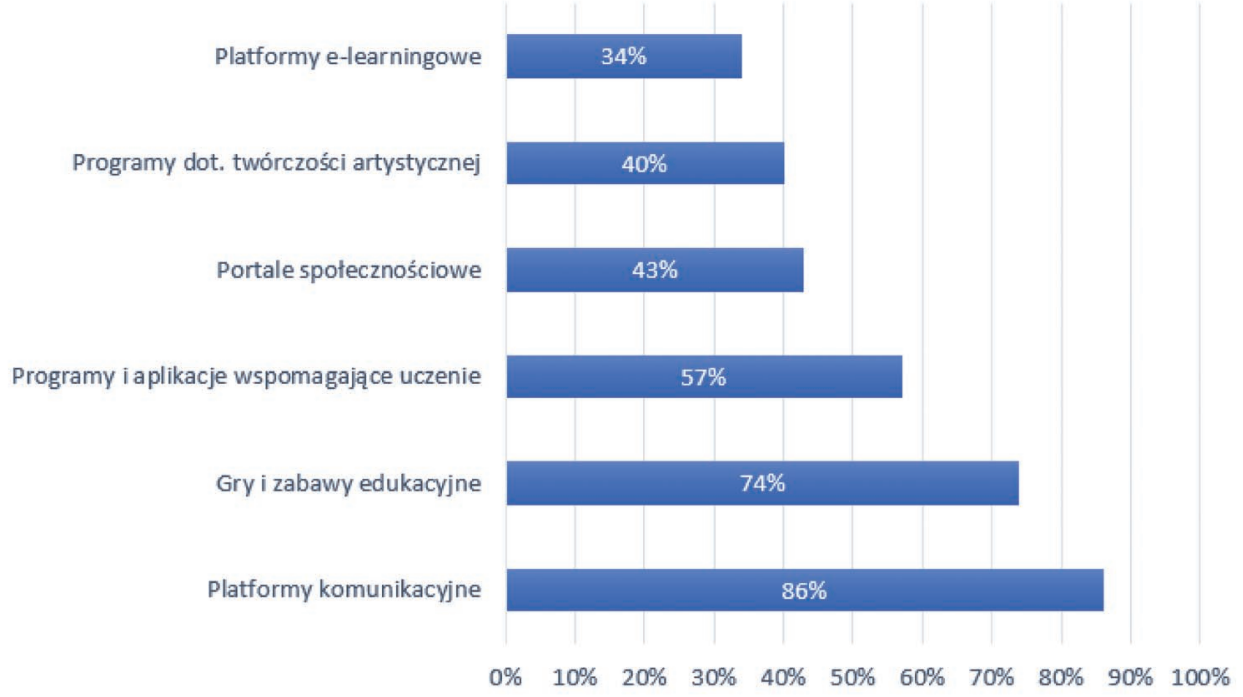

Ryc. 4. Narzędzia multimedialne wykorzystywane przez nauczycieli podczas nauczania zdalnego. Opracowanie własne

\section{Rola rodziców uczniów w podtrzymywaniu relacji interpersonalnych w klasie w warunkach zdalnego nauczania}

W warunkach zdalnego nauczania istotną rolę odgrywali również rodzice uczniów. To oni musieli zapewnić swoim dzieciom odpowiedni sprzęt i warunki do nauki. Ich wsparcie, zarówno techniczne, jak i emocjonalne, było kluczowe w dostosowaniu się ich dzieci do nowej sytuacji. Wsparcie to najczęściej polegało na pomocy przy odrabianiu lekcji oraz przy obsłudze komputera. Równie często rodzice zachęcali dzieci do ćwiczeń i pomagania $\mathrm{w}$ domowych obowiązkach. Nieco rzadziej okazywali zainteresowanie przeżyciami i problemami dziecka oraz uczestniczyli we wspólnych zabawach i grach. Precyzyjne dane uzyskane na ten temat $\mathrm{w}$ badaniu przedstawiono $\mathrm{w}$ tabeli 3 .

Tabela 3. Sposoby wsparcia dzieci ze strony rodziców

\begin{tabular}{|l|c|}
\hline Najczęstsze sposoby wsparcia dzieci ze strony rodziców & Liczba odpowiedzi \\
\hline Pomoc w odrabianiu lekcji & 33 \\
\hline Pomoc przy obsłudze komputera i programów komputerowych & 28 \\
\hline Zachęcanie do ćwiczeń, pomagania w obowiązkach domowych & 26 \\
\hline Okazywanie zainteresowania nastrojem/przeżyciami/problemami dziecka & 24 \\
\hline Wspólne zabawy/gry & 19 \\
\hline
\end{tabular}

Opracowanie własne 
Nauczanie zdalne wymusiło na rodzicach przeorganizowanie dotychczasowego planu dnia, ale dla ponad połowy respondentów (20 osób - 54\%) było to możliwe do osiągnięcia. W tym czasie bardzo istotna była komunikacja $\mathrm{z}$ nauczycielami. Zdecydowana większość rodziców (26 osób - 70\%) mogła liczyć na wsparcie pedagogów, z którymi kontaktowali się w różny sposób. Najczęściej były to rozmowy telefoniczne oraz e-maile. Rozmowy dotyczyły głównie trudności podczas zdalnego nauczania oraz instrukcji korzystania $z$ programów komputerowych.

\section{Wnioski}

Badania pokazują, że rodzice i nauczyciele odmiennie postrzegają funkcjonowanie relacji interpersonalnych na poziomie uczeń-uczeń. Rodzice w przeciwieństwie do nauczycieli nie dostrzegają zmian. Biorąc pod uwagę częstotliwość kontaktów rówieśniczych, należy stwierdzić, iż zmalała ona podczas pandemii, kontakty te przez większość uczniów są jednak podtrzymywane, głównie dzięki wideorozmowom. Na poziomie relacji uczeń-nauczyciel kontakty te nie uległy wielkim zmianom, a jeśli taka zmiana nastąpiła, to objawiała się głównie zwiększeniem dystansu. Nauczyciele musieli w takich wypadkach zwiększyć starania o podtrzymywanie relacji z uczniami na dobrym poziomie, a także sprawić, by stosunki między dziećmi nie pogorszyły się mimo nauczania na odległość. Stosowali zatem rozmaite formy, metody pracy oraz narzędzia multimedialne, co owocowało podtrzymywaniem kontaktów w klasie na dobrym poziomie. Należy jednak pamiętać, iż równie ważna w podtrzymywaniu relacji w klasie jest rola rodzica, bez którego wsparcia dzieciom trudno byłoby uporać się z nową rzeczywistością.

Badanie „Zdalne nauczanie a adaptacja do warunków społecznych w czasie epidemii koronawirusa" z 2020 r. wykazuje podobieństwo do badań własnych przeprowadzonych w lutym $2021 \mathrm{r}$. Respondenci z obu grup zauważyli zmiany w kontaktach rówieśniczych między uczniami oraz niezmienność relacji na poziomie nauczyciel-uczeń. W badaniach A. Buchner, M. Majchrzak i M. Wierzbickiej z $2020 \mathrm{r}$. oraz w badaniach własnych można zauważyć podobieństwo niejednorodnych relacji rodzica $z$ nauczycielem. Duża część rodziców nie odczuwa wsparcia ze strony nauczyciela, w związku z czym mogą się rodzić różne problemy podczas komunikacji. 


\section{Zakończenie}

Relacje interpersonalne są niezwykle ważne w prawidłowym funkcjonowaniu człowieka. Czas pandemii jest jednak okresem, kiedy relacje te są wystawione na próbę. Jest to trudne, zwłaszcza dla dzieci. Zdalne nauczanie i inne restrykcje nie pozwalają na utrzymywanie bezpośrednich kontaktów z drugą osobą. To sprawiło, że niektóre relacje uległy zmianom. Podtrzymywanie ich w klasie było bardzo istotne z perspektywy społeczno-emocjonalnego rozwoju dziecka, a dzięki odpowiednim działaniom ze strony nauczycieli oraz rodziców kontakty te w większości przypadków były nadal podtrzymywane.

\section{Bibliografia}

Bieganowska-Skórka, A., Pankowska, D. (2020). Moje s@mopoczuciew e-szkole. Raport z badań, https://phavi.umcs.pl/at/attachments/2020/1126/112228-moje-samopoczucie-w-e-szkole-raportz-badan.pdf (dostęp 21 II 2021).

Buchner, A., Majchrzak, M., Wierzbicka, M. (2020). Edukacja zdalna w czasie pandemii. Raport (edycja I), https://centrumcyfrowe.pl/wp-content/uploads/sites/16/2020/05/Edukacja_zdalna_w_czasie_pandemii.pptx-2.pdf (dostęp 27 II 2021).

Buchner, A., Wierzbicka, M. (2020). Edukacja zdalna w czasie pandemii. Raport (edycja II), https:// centrumcyfrowe.pl/wp-content/uploads/sites/16/2020/11/Raport_Edukacja-zdalna-w-czasiepandemii.-Edycja-II.pdf (dostęp 27 II 2021).

Doucet, A., Netolicky, D., Timmers, K., Tuscano, F. J. (2020). Thinking about Pedagogy in an Unfolding Pandemic. An Independent Report on Approaches to Distance Learning during COVID19 School Closures, https://issuu.com/educationinternational/docs/2020_research_covid-19_eng (dostęp 6 IV 2021).

Dubis, M. (2017). Specyfika relacji interpersonalnej nauczyciel-uczeń w przestrzeni edukacyjnej $i$ wychowawczej. „Pedagogika Przedszkolna i Wczesnoszkolna”, 2 (10), s. 5-17.

Jakimiuk, B. (2016). Praca nauczyciela jako obszar budowania relacji interpersonalnych. „Szkoła - Zawód - Praca", 11, s. 118-128.

Musiał, E. (2016). Relacje uczeń-nauczyciel kluczem do udanego nauczania. „Edukacja — Technika Informatyka”, 3/17, s. 221-226.

Poleszak, W., Pyżalski, J. (2020). Relacje przede wszystkim - nawet jeśli obecnie jedynie zapośredniczone, W: J. Pyżalski (red.), Edukacja w czasach pandemii wirusa COVID-19. Z dystansem o tym, co robimy obecnie jako nauczyciele. Warszawa: EduAkcja, s. 28-36.

Ptaszek, G., Stunża, G. D., Pyżalski, J., Dębski, M., Bigaj, M. (2020). Edukacja zdalna, co stało sie z uczniami, ich rodzicami i nauczycielami? Gdańsk: GWP.

Pyżalski, J. (2020). Co jest obecnie ważne, a co mniej w działaniach szkót i nauczycieli? W: J. Pyżalski (red.), Edukacja w czasach pandemii wirusa COVID-19. Z dystansem o tym, co robimy obecnie jako nauczyciele. Warszawa: EduAkcja, s. 25-27.

Pyżalski, J., Stunża, G. (2020). Co się stało z relacjami uczniów, rodziców i nauczycieli w czasie pandemii? W: G. Ptaszek, M. Bigaj, M. Dębski, J. Pyżalski, G. D. Stunża (red.), Zdalna edukacja - gdzie byliśmy, dokad idziemy? Wstępne wyniki badania naukowego „Zdalne nauczanie a adaptacja do warunków społecznych w czasie epidemii koronawirusa”, s. 21-27, https://ug.edu.pl/news/sites/ug.edu. pl.news/files/2020-06/Badanie\%20zdalnenauczanie_prezentacja_1.pdf (dostęp 6 IV 2021). 
Stringer, H. (2020). Zoom School's Mental Health Toll on Kids: Academic and social development are likely to slip during online learning for many students, https://www.apa.org/news/apa/2020/10/online-learning-mental-health (dostęp 6 IV 2021).

Wolska, A. (2021). Budowanie relacji interpersonalnych w klasie w czasach pandemii, W: COVID-19Spojrzenie Młodych Naukowców - streszczenia wystapień. Materiaty konferencyjne. Kraków: Creativetime.

Zborowski, Z. (1974). Stosunki międzyludzkie a wychowanie. Warszawa: Nasza Księgarnia. 